\section{Can profit and loss sharing (PLS) financing instruments reduce the credit risk of Islamic banks?}

By: Farihana, S (Farihana, Shahari) ${ }^{[1]}$; Rahman, MS (Rahman, Md. Saifur) ${ }^{[2]}$

EMPIRICAL ECONOMICS

DOI: $10.1007 / \mathrm{s} 00181-020-01912-5$

园 Early Access: JUL 2020

Document Type: Article; Early Access

View Journal Impact

\section{Abstract}

An Islamic bank is an interest-free financial institution that is growing rapidly in both Muslim and non-Muslim countries. It provides loans based on both PLS and non-PLS concepts, where the PLS concept shares both profit and loss with the customers, while the non-PLS concept allows charging a fixed profit rate. The customers are treated as partners who invest either labor or an equal portion of capital. The PLS financing raises an issue of whether the Islamic bank is able to recover the financing amount which is disbursed without any form of collateral. Therefore, this paper explores the possible implication of PLS theory and examines whether the PLS financing instrument reduces the credit risk of Islamic banks. PLS financing is a focus variable, while bank-specific and macroeconomic variables are considered as control variables that enable us to draw a reliable and unbiased result. The study evaluates several hypotheses by employing two-step system GMM estimation technique. It offers several outcomes; PLS financing instrument reduces credit risk. The bank-specific and macroeconomic variables have a mixed effect on credit risk. The study suggests significant policy implications for the Islamic banks for sustaining the competitive banking industries.

\section{Keywords}

Author Keywords: Islamic banks; PLS financing instrument; Credit risk; System GMM; Macroeconomy

KeyWords Plus: DETERMINANTS; BUSINESS; BEHAVIOR; GROWTH

\section{Author Information}

Reprint Address:

Royal Melbourne Institute of Technology (RMIT) RMIT Univ, Dept Econ Finance \& Mkt, Coll Business, Melbourne, Vic, Australia Corresponding Address: Rahman, MS (corresponding author)

+ RMIT Univ, Dept Econ Finance \& Mkt, Coll Business, Melbourne, Vic, Australia.

\section{Addresses:}

+ [1] Int Islamic Univ Malaysia, Dept Finance Kulliyyah Econ \& Management Sci, Kuala Lumpur 53100, Gombak, Malaysia

+ [2 ] RMIT Univ, Dept Econ Finance \& Mkt, Coll Business, Melbourne, Vic, Australia

E-mail Addresses: farihana_shahari iium.edu.my; masaifur yahoo.com

Funding

\begin{tabular}{|l|l|}
\hline Funding Agency & Grant Number \\
\hline IIUM Research Management Center & KENMS-RG19-006-0006 \\
\hline
\end{tabular}

View funding text

Publisher

PHYSICA-VERLAG GMBH \& CO, PO BOX 1052 80, 69042 HEIDELBERG, GERMANY

Journal Information

Impact Factor: Journal Citation Reports

Categories / Classification

Research Areas: Business \& Economics; Mathematical Methods In Social Sciences

\section{Citation Network}

In Web of Science Core Collection

0

Times Cited

Create Citation Alert

40

Cited References

View Related Records

Use in Web of Science

Web of Science Usage Count

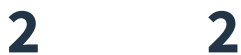

Last 180 Days $\quad$ Since 2013

Learn more

This record is from:

Web of Science Core Collection

- Social Sciences Citation Index

Suggest a correction

If you would like to improve the quality of the data in this record, please suggest a correction. 
Web of Science Categories: Economics; Social Sciences, Mathematical Methods

See more data fields

1 of 1

\section{Cited References: 40}

1. Failure and potential of profit-loss sharing contracts: A perspective of New Institutional, Economic (NIE) Theory

4. Financial liberalization, financial sector development and growth: Evidence from Malaysia

5. ANOTHER LOOK AT THE INSTRUMENTAL VARIABLE ESTIMATION OF ERROR-COMPONENTS MODELS

By: ARELLANO, M; BOVER, O

JOURNAL OF ECONOMETRICS Volume: 68 Issue: 1 Pages: 29-51 Published: JUL 1995

6. An empirical analysis of credit risk factors of the Slovenian banking system By: Aver, B.

Managing Global Transitions Volume: 6 Issue: 3 Pages: 317-334 Published: 2008

7. Initial conditions and moment restrictions in dynamic panel data models

8. Bank specific, business and institutional environment determinants of banks nonperforming loans: evidence from MENA

9. Is credit risk really higher in Islamic banks?

By: Boumediene, Aniss

JOURNAL OF CREDIT RISK Volume: 7 Issue: 3 Pages: 97-129 Published: FAL 2011

10. Understanding the behavior of bank spreads in Latin America

Times Cited: 102

By: Brock, PL; Suarez, LR

JOURNAL OF DEVELOPMENT ECONOMICS Volume: 63 Issue: 1 Special Issue: SI Pages: 113-134 Published: OCT 2000

11. Macroeconomic determinants of the credit risk in the banking system: The case of the GIPSI

Times Cited: 78

By: Castro, Vitor

ECONOMIC MODELLING Volume: 31 Pages: 672-683 Published: MAR 2013

12. Islamic banking: Interest-free or interest-based?

Times Cited: 254

By: Chong, Beng Soon; Liu, Ming-Hua

PACIFIC-BASIN FINANCE JOURNAL Volume: 17 Issue: 1 Pages: 125-144 Published: JAN 2009

13. Determinants of credit risk in indian state-owned banks: an empirical investigation

By: Das, A; Ghosh, S.

MPRA paper, No. 1 Published: 2007

URL: http://mpra.ub.uni-muenchen.de/17301/ 